Nutrition Research Reviews, published annually by Cambridge University Press, presents authoritative and critical reviews of research that advance new concepts and encourage fresh thinking on a variety of nutritional problems. The journal's main objective is to encourage the exchange of fundamental ideas on nutritional well-being. The subscription (excluding VAT) to volume 8,1995 , is $£ 49$ including postage (US $\$ 89$ in USA, Canada and Mexico).

The Proceedings of the Nutrition Society, published by Cambridge University Press, in part record meetings of the Symposium type, at which experts in a particular field are invited by Council to make contributions on specific parts of it and at which general discussion follows these invited contributions. The meetings also include sessions at which papers are communicated by members and others on original work. It is proposed at present to publish summaries of the papers read at each meeting, each communication being recorded in the Society's Proceedings by means of an abstract not exceeding in length 400 words or the equivalent space in print. The Proceedings are published three times a year.

The subscription (excluding VAT) to the Proceedings is $£ 126.00$ (US $\$ 240.00$ in USA, Canada and Mexico). Single issues are $£ 44.00$ (US $\$ 85.00$ in the USA, Canada and Mexico) each; postage extra.

Copying. This journal is registered with the Copyright Clearance Center, 222 Rosewood Drive, Danvers, MA 01923. Organizations in the USA who are also registered with C.C.C. may therefore copy material (beyond the limits permitted by sections 107 and 108 of the US copyright law) subject to payment to C.C.C. of the per-copy fee of $\$ 11.00$. This consent does not extend to multiple copying for promotional or commercial purposes. Code $0007-1145 / 95 \$ 11.00+.10$. Organizations authorized by the Copyright Licensing Agency may also copy material subject to the usual conditions.

ISI Tear Sheet Service, 3501 Market Street, Philadelphia, Pennsylvania 19104, USA, is authorized to supply single copies of separate articles for private use only.

For all other use, permission should be sought from Cambridge or the American Branch of Cambridge University Press.

\title{
INDEX OF AUTHORS
}

\begin{tabular}{|c|c|c|c|c|c|}
\hline Amor, $\mathrm{S}$. & 701 & Hornstra, G. & 723 & Schröder, B. & 635 \\
\hline & & Hovenier, $\mathbf{R}$. & 689 & Secher, N. J. & 723 \\
\hline Barker, M. E. & 649 & & & Simonis, M. M. G. & 723 \\
\hline Berner, Y. & 681 & Käppner, H. & 635 & Sørensen, J. D. & 723 \\
\hline Beynen, A. C. & 689 & & & Southgate, D. A. T. & 605 \\
\hline Bolton-Smith, C. & 661 & Madar, $\mathrm{Z}$. & 607,681 & Spiller, R. C. & 733 \\
\hline Boris, J. & 723 & Manor, E. & 681 & & \\
\hline Breves, G. & 635 & McClean, S. I. & 649 & Tamminga, $\mathrm{S}$. & 617 \\
\hline Brown, C. A. & 661 & McCluskey, M.-K. & 661 & Thompson, K. A. & \\
\hline Cohen-Melamed, E. & 607 & Nordøy, E, S. & 717 & Thompson, L. & 73 \\
\hline Crawford, M. A. & 701 & Norenberg, C. & 681 & & \\
\hline Dijkstra, J. & 617 & Nyska, A. & 607 & 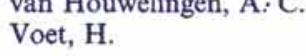 & \\
\hline Dingle, J. G. & 671 & Ølsen, S. F. & 723 & & \\
\hline $\begin{array}{l}\text { Failing, K. } \\
\text { Feldman, N. }\end{array}$ & $\begin{array}{l}635 \\
681\end{array}$ & Pfeffer, E. & 635 & $\begin{array}{l}\text { West, C. E. } \\
\text { Wiryawan, K. G. }\end{array}$ & 671 \\
\hline Fenton, S. & 661 & Pollack, A. & 607 & Woodward, M. & \\
\hline Harbige, L. S. & 701 & Roodenburg, A. J. C. & 689 & Yeatman, N. & 10 \\
\hline
\end{tabular}




\section{CONTENTS}

\section{Editorial}

The structure of scientific papers. D. A. T. Southgate

Acarbose and cataract formation

Aldose reductase (EC 1.1.1.21) activity and reduced-glutathione content in lenses of diabetic sand rats (Psammomys obesus) fed with acarbose. Ester CohenMelamed, A. Nyska, A. Pollack \& Z. Madar

Protozoal contribution to fibre degradation

Simulation of the effects of diet on the contribution of rumen protozoa to degradation of fibre in the rumen. Jan Dijkstra \& Seerp Tamminga

Intestinal phosphate transport

Mechanisms of intestinal phosphate transport in small ruminants. B. Schroder, H. Käppner, K. Failing, E. Pfeffer \& G. Breves

Attitudes and diet

Attitudinal dimensions of food choice and nutrient intake. Margo E. Barker, Kate A. Thompson \& Sally I. McClean

Trans fatty acid intake

Trans fatty acids in the Scottish diet. An assessment using a semi-quantitative food-frequency questionnaire. C. Bolton-Smith, M. Woodward, S. Fenton, M. K. McCluskey \& the late C. A. Brown

Protein quality of grain legumes for poultry

Screening tests of the protein quality of grain legumes for poultry production. K. G. Wiryawan \& J. G. Dingle

Locust-gum fibre lowers glycaemic response

Enrichment of an Israeli ethnic food with fibres and their effects on the glycaemic and insulinaemic responses in subjects with non-insulin-dependent diabetes mellitus. Nira Feldman, Clara Norenberg, Hillary Voet, Ester Manor, Yishal Berner \& Zecharia Madar

Vitamin A and iron metabolism

Evaluation of a two-generation rat model for vitamin A deficiency and the interrelationship with iron metabolism. Annet J. C. Roodenburg, Clive E. West, Robert Hovenier \& Anton C. Beynen

$\gamma$-Linolenic acid and encephalomyelitis

Prevention of experimental autoimmune encephalomyelitis in Lewis rats by a novel source of $\gamma$-linolenic acid. L. S. Harbige, N. Yeatman, S. Amor \& M. A. Crawford 